Bangl. J. Vet. Med. (2010). 8(1): $57-61$

\title{
COMPARATIVE EFFICACY OF STEVIA LEAF (STEVIA REBAUDIANA BERTON), METHI SEEDS (TRIGONELLA FOENUM-GRAECUM) AND GLIMEPIRIDE IN STREPTPZOTOCIN INDUCED DIABETEIC RATS
}

\author{
M. Mostofa ${ }^{1}$, Kazi Rafiq ${ }^{1,2}$, Akira Nishiyama ${ }^{2}$, B. C. Barman ${ }^{1}$ and Shamshad J. Sherajee ${ }^{2}$ \\ ${ }^{1}$ Department of Pharmacology, Bangladesh Agricultural University, ${ }^{2}$ Department of Pharmacology, Medical \\ School of Kagawa University, Japan
}

\begin{abstract}
Medicinal plants are becoming very popular for the treatment of different diseases all over the world. The present study was conducted during January 2009 to June 2009 and investigated the effects of Stevia (Stevia rebaudiana Bertoni) leaves, methi (Trigonella foenum-graecum) seeds in terms of their hypoglycemic activity compared to Glimepiride (Amaryl ${ }^{\mathbb{B}}$, Aventies Pharmaceuticals). Diabetes was induced experimentally in the rats with Streptozotocin (STZ; $55 \mathrm{mg} / \mathrm{kg}$, i.p.). Stevia, methi, combination of stevia-methi extracts and Amaryl ${ }^{\circledR}$ tablet were orally administered daily at the rate of $100 \mathrm{mg} / \mathrm{kg}, 500 \mathrm{mg} / \mathrm{kg}$, $500 \mathrm{mg} / \mathrm{kg}$ and $800 \mu \mathrm{g} / \mathrm{kg}$ respectively after 15 days of STZ injection for a period of 60 days. Changes in the blood glucose levels and body weights were measured and the results were compared statistically. The combined stevia-methi extract showed potent hypoglycemic effect than stevia and methi alone. STZ-induced body weight loss was improved in all groups except stevia treatment group.
\end{abstract}

Key words: Stevia, methi, glimepiride, STZ-induce diabetic rats

\section{INTRODUCTION}

The worldwide prevalence of diabetes is increasing at such a rapid that the World Health Organization (WHO) has identified diabetes as an epidemic condition (King et al, 1991). An estimate by WHO, there will be about 250 million cases of diabetes mellitus throughout the world by 2025 (Friedman, 2002). In Bangladesh about 5 million people are suffering from diabetes. This disease alone ranks among the top ten causes of death in western world (Cotran et al, 1989). Since the discovery of insulin in 1922, it has been used successfully in insulin-dependent diabetes mellitus (IDMM). But it can not be given orally, daily intake through injection is obviously troublesome and hypoglycemic reactions as an adverse effect may occur in any diabetic patient treated with it. Again insulin resistance, a state of relative tissue insensitivity to the action of insulin, is another drawback for patients taking it for a long period (Larner, 2001). On the other hand, oral hypoglycemic agents such as glimepiride, glibenclamide have some adverse effects such as vomiting, epigastric discomfort, jaundice, headache etc. Traditional medicinal plants are being used throughout the world for a range of anti-diabetic preparations and prior to the availability of insulin, dietary measures (Khajuria and Thomas, 1992), the traditional medicines derived from plants, were the major forms of treatment (Bailey and Day, 1989). Ethnobotanical studies of traditional herbal remedies used for diabetes around the world have identified more than 1,200 species of plants with hypoglycemic activity (Marles and Farnsworth, 1995). The study of such agents might offer a natural key to unlock a diabetologist's pharmacy for future.

Stevia (Stevia Rebaudiana Bertoni) is an herbaceous native South American perennial plant containing two major compounds, stevioside and rebaudioside. It is reported that Steviosides has insulinotropic effects in the beta-cell (in vitro), increase the insulin secretion and thereby decreasing blood glucose level. Oviedo et al (1979) found an antihyperglycemic effect in rats when supplementing the diet with dried Stevia rebaudiana leaves. Trigonella foenum-graecum commonly known as methi which effect on blood glucose was evaluated in diabetic patients. Seeds have been shown to be hypoglycemic in normal and mildly diabetic animals but not in those with severe disease (Bailey and Day, 1989). Defatted seeds lowered blood glucose as well as glucagon in dogs both normal and diabetic. Amary ${ }^{\mathbb{B}}$ Tablet (Glimepiride) was emerged from Sulfonylureas cause hypoglycemia by (a) stimulating insulin release from pancreatic $\beta$ cells, (b) reduction of serum glucagon level and (c) increased binding of insulin to the target tissue or receptor. Cetto et al. (2000) reported that a single oral administration of glibenclamide @ $3 \mathrm{mg} / \mathrm{kg}$ lowered the plasma glucose levels in diabetic rats within three hours of administration. Considering the above, our objectives was to study the effect of aqueous extract of the Stevia (Stevia rebaudiana Bertoni), Methi (Trigonella foenum-graecum) leaves on fasting blood glucose and body weight compare to glimepiride $\left(\right.$ Amaryl $^{\mathbb{B}}$ ) in streptozotocin-induced diabetic rats. 


\section{Mostofa and others}

\section{MATERIALS AND METHODS}

The proposed experiment on conducted in the Department of Pharmacology, Bangladesh Agricultural University (BAU) during the period from January 2009 to June 2009.

\section{Experimental Rats}

The experiment was carried out on 30 apparently healthy rats of Long Evans (Ratus norvegicus) rats having 5 weeks age matching and weighing between 100 to $150 \mathrm{~g}$ weights. The rats were collected from International Center of Diarrhea Disease Research (ICDDR'B), Dhaka, Bangladesh. During the experimental period, the rats were fed food in pellet form and tap water was supplied ad libitum. The rats were maintained in this condition for a period of one week to acclimatize them prior to experimental uses.

\section{Plant materials}

Young Stevia plants were collected from BRAC tissue culture nursery at Joydevpur, Gazipur and then were reared for about three months on the roof of the Building-2, Faculty of Veterinary Science, Bangladesh Agricultural University, Mymensingh. Fresh Stevia leaves were obtained from that garden. Fresh methi leaves were collected from the Botanical Garden of BAU Campus and tablet Amaryl ${ }^{\circledR}$ were collected from K.R Market of BAU. The plants were authenticated from the Department of Botany, BAU, Mymensingh, Bangladesh.

Fresh Stevia leaves that were collected from the garden were oven dried first and then dried leaves were grinded with Grinder machine. Then $1 \mathrm{~g}$ dried leaves samples were mixed with $10 \mathrm{ml}$ distilled water and were allowed to stay for whole night. Everyday new extract were prepared following these techniques. Water extract of methi was made from $100 \mathrm{~g}$ fresh seed sample by grinding with Grinder machine, and mixed with $2000 \mathrm{ml}$ distilled water. Then the water extract was lyophilized collected as powder form by Freeze drying in Central Laboratory, BAU.

\section{Induction of diabetes}

Streptozotocin (STZ) was dissolved in $0.1 \mathrm{M}$ citrate buffer having $\mathrm{pH}$ 4.5. To induce diabetic condition in rats STZ injected $55 \mathrm{mg} / \mathrm{kg}$ body weight intraperitoneal as done previously. STZ injection rapidly produced the characteristic signs of diabetes, such as increased intake of food and water, frequent urination and increased blood glucose concentration. After one week of STZ injection rats having more than $250 \mathrm{mg} / \mathrm{dl}$ random blood glucose concentrations and showing above-mentioned characteristic signs of diabetes were selected for this experiment. Blood samples were collected for blood glucose measurements at alternate weeks.

\section{Experimental design}

Experimental 30 rats were divided into 6 groups $(\mathrm{n}=5)$ and treated intraperitoneal as follows: group-A as control (Con, without STZ). STZ-induced diabetic rats were divided into five groups (groups B, C, D, E, F) each consisting 5 rats. Group-B; diabetic control (STZ). Group-C; STZ + aqueous extract of stevia leaves @100 $\mathrm{mg} / \mathrm{kg}$, Group-D; STZ+ aqueous extract of methi leaves @ $500 \mathrm{mg} / \mathrm{kg} /$,Group-E; STZ+ combination of aqueous extract of stevia and methi leaves @ $500 \mathrm{mg} / \mathrm{kg}$, and group-F, Tablet Amaryl ${ }^{\mathbb{B}}$ (glimepiride, Aventis) @ 800 $\mu \mathrm{g} / \mathrm{kg}$.

\section{Statistical analysis}

Data was expressed as Mean \pm Standard Deviation of Means.Statistical analysis was made by using Student's unpaired t-test.

\section{RESULTS AND DISSCUSSION}

Diabetes mellitus is a complex disorder or more properly described as a malfunction of the Pancreas (Adams, 1995). Hyperglycemia is the most critical problems in the diabetes with generally, decrease of body weight as progress of diabetes (Kamalakkannan et al., 2003). Therefore, the hypoglycemic (Mahomed and Ojewole, 2003) as well as body weight maintaining effects have been considered as the essential characteristics of an antidiabetic agent, and the efficacy of this herbal extracts has been screened primarily based on these effects.

In this study, Streptozotocin injection in rats showed significant $(p<0.001)$ increase in blood glucose level and reduction of body weight. Chowdhury et al (2005) shown that a single dose of Streptozotocin $(50 \mathrm{mg} / \mathrm{kg}$, intraperitonially) in rats exhibited characteristic signs of diabetic. Following treatment with Glimepiride $\left(\right.$ Amaryl $\left.^{\circledR}\right)$, blood glucose level was reduced significantly $(\mathrm{P}<0.001)$. Amanullah et al (2008) also reported significant reduction in blood glucose level with Glimepiride @ $800 \mu \mathrm{g} / \mathrm{kg}$. Some other authors also reported the 
reduction of blood glucose level following administration of Stevia (Stevia rebaudiana Bertoni) leaves. (Chang et al., 2005, Raskovic et al., 2004, Jeppesen et al., 2003). In this study treatment with Methi (Trigonella foenumgraecum) and Talekucha (Coccinia indica) was significantly reduced $(\mathrm{P}<0.01)$ blood glucose level. Choudhury et al (2005) reported the reduction of blood glucose following administration of methi seed extract, our previous study and other researcher also support present study data Devi et al(2003), Vats et al (2002),Raju J et al (2001), Mostofa et al (2007), M.H.Sumon et al(2008) . However, in this study we observed that combination of stevia and methi showed better hypoglycemic effects then that of single therapy in STZ-induced rats.

Antihyperglycemic effect of aqueous extracts of indigenous medicinal plants in STZ-induced diabetic rats

From beginning to end the blood glucose concentration of normal control rats (Group A) was $5.47 \pm 0.10$ to $5.55 \pm 0.56 \mathrm{mmol} / \mathrm{L}$ and in the diabetic control rats (GroupB ) after Streptozotocin injection the blood glucose concentration on day 0 was $21.01 \pm 0.83$ and on day 60 was $24.02 \pm 78 \mathrm{mmol} / \mathrm{L}$. In Group C, the blood glucose concentration of stevia $(100 \mathrm{mg} / \mathrm{kg})$ leaves extract treated group on day 0 was $23.08 \pm 0.47 \mathrm{mmol} / \mathrm{L}$ and on 60 day was $17.05 \pm 0.34 \mathrm{mmol} / \mathrm{L}$. In Group D, the blood glucose concentration of Methi seeds extract $(500 \mathrm{mg} / \mathrm{kg})$ treated group on day 0 was $22.02 \pm 0.24 \mathrm{mmol} / \mathrm{L}$ and on day $6016.10 \pm 0.56 \mathrm{mmol} / \mathrm{L}$. In Group E, the blood glucose concentration of combination of stevia and methi leaves extract treatment $(500 \mathrm{mg} / \mathrm{kg})$ on day 0 was $24.05 \pm 0.04$ $\mathrm{mmol} / \mathrm{L}$ and on day 60 was $16.02 \pm 0.11 \mathrm{mmol} / \mathrm{L}$. In Group F, the blood glucose concentration of Glimepiride (Amaryl ${ }^{\circledR} @ 800 \mu \mathrm{g} / \mathrm{kg}$ ) treated group on day 0 was $23.63 \pm 0.35 \mathrm{mmol} / \mathrm{L}$ and on day 60 was $10.02 \pm 0.54 \mathrm{mmol} / \mathrm{L}$ (Table 1).

Table 1. Changes on blood glucose concentration (mean $\pm \mathrm{SD}, \mathrm{m} \mathrm{mol} / \mathrm{L}$ ) in groups of normal and Streptozotocin (STZ) induced diabetic Rats

\begin{tabular}{|c|c|c|c|c|c|c|c|}
\hline \multirow{2}{*}{ 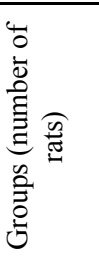 } & \multirow[t]{2}{*}{ Drug, dose and route } & \multirow{2}{*}{$\begin{array}{l}\begin{array}{l}\text { Pre- } \\
\text { treatment }\end{array} \\
\text { Day } 0\end{array}$} & \multicolumn{4}{|c|}{ Post-treatment } & \multirow[b]{2}{*}{$\begin{array}{c}\text { \% Increase }(+) \\
\text { decrease }(-) \\
\text { in blood glucose } \\
\text { level }\end{array}$} \\
\hline & & & Day 14 & Day 28 & Day 42 & Day60 & \\
\hline $\mathrm{A}(\mathrm{n}=5)$ & Normal control & $5.47 \pm 0.10$ & $5.49 \pm 0.34$ & $5.50 \pm 0.23$ & $5.53 \pm 0.32$ & $5.55 \pm 0.56$ & +2.00 \\
\hline $\mathrm{B}(\mathrm{n}=5)$ & Diabetic control & $21.01 \pm 0.83$ & $22.06 \pm 0.34$ & $23.00 \pm 0.23$ & $23.09 \pm 0.56$ & $24.02 \pm 78$ & +13.00 \\
\hline$C(n=5)$ & $\begin{array}{l}\text { Stevia leaves } \\
\text { extracts @ } 100 \mathrm{mg} / \mathrm{kg} \\
\text { orally }\end{array}$ & $23.08 \pm 0.47$ & $22.06 \pm 0.04$ & $20.00 \pm 0.34$ & $18.09 \pm 0.34$ & $17.05 \pm 0.34$ & -26 \\
\hline $\mathrm{D}(\mathrm{n}=5)$ & $\begin{array}{l}\text { Methi leaves extract } \\
\text { @ } 500 \mathrm{mg} / \mathrm{kg} \text {, orally }\end{array}$ & $22.02 \pm 0.24$ & $21.09 \pm 0.21$ & $19.08 \pm 0.56$ & $17.06 \pm 0.32$ & $16.10 \pm 0.56$ & -28 \\
\hline$E(n=5)$ & $\begin{array}{l}\text { Combined stevia and } \\
\text { methi extract@ } \\
500 \mathrm{mg} / \mathrm{kg} \text {, orally }\end{array}$ & $24.05 \pm 0.04$ & $23.01 \pm 0.12$ & $21.09 \pm 0.12$ & $14.05 \pm 0.67$ & $16.02 \pm 0.11$ & -34 \\
\hline$F(n=5)$ & 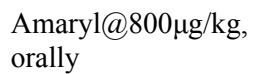 & $23.63 \pm 0.35$ & $21.05 \pm 0.75$ & $20.04 \pm 0.43$ & $13.06 \pm 0.34$ & $10.02 \pm 0.54$ & -57 \\
\hline
\end{tabular}

Effect of aqueous extracts of indigenous medicinal plants on body weight gain in STZ-induced diabetic rats

In this present study, at day 0 and day 90 of treatment, average body weight of control and STZ groups were $136.20 \pm 5.24 \mathrm{~g}, 124.00 \pm 7.11 \mathrm{~g}$ and $136.92 \pm 5.22 \mathrm{~g}, 121.57 \pm 7.26 \mathrm{~g}$ respectively. On the other hand treatment with stevia leaf extracts lowered body weight gain $1.6 \%$. At day 0 and day 90 of treatment, methi seed extract treatment showed $124.80 \pm 7.76 \mathrm{~g}, 128.25 \pm 6.98 \mathrm{~g}$ body weight. Combined stevia and methi extracts $(500 \mathrm{mg} / \mathrm{kg})$ showed $125.40 \pm 8.08 \mathrm{~g}$ and $130.40 \pm 8.17 \mathrm{~g}$ body weight at day 0 and day 90 respectively. At day 0 and day 90 of treatment, tablet Amaryl $(800 \mu \mathrm{g} / \mathrm{kg})$ treatment group showed $125.65 \pm 5.13 \mathrm{~g}$ and $132.85 \pm 4.96 \mathrm{~g}$ body weight respectively (Table 2) 


\section{Mostofa and others}

Table 2. Changes on body weights (mean $\pm \mathrm{SD}, \mathrm{g}$ ) in groups of normal and Streptozotocin (STZ) induced diabetic rats

\begin{tabular}{|c|c|c|c|c|c|c|c|c|}
\hline \multirow{2}{*}{ 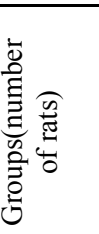 } & \multirow[t]{2}{*}{ Drug, dose and route } & \multirow{2}{*}{$\begin{array}{c}\text { Pre- } \\
\text { treatment }\end{array}$} & \multicolumn{5}{|c|}{ Post-treatment } & \multirow{2}{*}{$\begin{array}{c}\% \\
\text { Increase }(+) \\
\text { decrease(-) } \\
\text { in body } \\
\text { weight }\end{array}$} \\
\hline & & & Day 14 & Day 28 & Day 42 & Day60 & Day 90 & \\
\hline $\mathrm{A}(\mathrm{n}=5)$ & Normal control & $\begin{array}{l}136.20 \pm \\
5.24\end{array}$ & $\begin{array}{l}136.36 \pm \\
5.33\end{array}$ & $\begin{array}{l}136.61 \pm \\
5.06\end{array}$ & $\begin{array}{l}136.70 \pm \\
5.02\end{array}$ & $\begin{array}{l}136.70 \pm \\
5.14\end{array}$ & $\begin{array}{l}136.92 \pm \\
5.22\end{array}$ & +0.53 \\
\hline$B(n=5)$ & Diabetic control & $\begin{array}{l}124.00 \pm \\
7.11\end{array}$ & $\begin{array}{l}123.06 \pm \\
0.34\end{array}$ & $\begin{array}{l}123.07 \pm \\
0.23\end{array}$ & $\begin{array}{l}122.14 \pm \\
0.56\end{array}$ & $\begin{array}{l}122.02 \pm \\
0.78\end{array}$ & $\begin{array}{l}121.57 \pm \\
7.26\end{array}$ & -2.0 \\
\hline$C(n=5)$ & $\begin{array}{l}\text { Stevia leaves extracts } \\
\text { @ } 100 \mathrm{mg} / \mathrm{kg} \text { orally }\end{array}$ & $\begin{array}{l}125.15 \pm \\
8.16\end{array}$ & $\begin{array}{l}124.14 \pm \\
0.34\end{array}$ & $\begin{array}{l}124.06 \pm \\
0.74\end{array}$ & $\begin{array}{l}123.13 \pm \\
0.64\end{array}$ & $\begin{array}{l}123.12 \pm \\
0.34\end{array}$ & $\begin{array}{l}123.10 \pm \\
7.94\end{array}$ & -1.6 \\
\hline$D(n=5)$ & $\begin{array}{l}\text { Methi leaves extract } \\
\text { (a) } 500 \mathrm{mg} / \mathrm{kg} \text {, orally }\end{array}$ & $\begin{array}{l}124.80 \pm \\
7.76\end{array}$ & $\begin{array}{l}125.06 \pm \\
0.24\end{array}$ & $\begin{array}{l}125.23 \pm \\
0.34\end{array}$ & $\begin{array}{l}126.11 \pm \\
0.34\end{array}$ & $\begin{array}{l}127.16 \pm \\
0.34\end{array}$ & $\begin{array}{l}128.25 \pm \\
6.98\end{array}$ & +3.0 \\
\hline$E(n=5)$ & $\begin{array}{l}\text { Combined stevia and } \\
\text { methi extract@ } \\
500 \mathrm{mg} / \mathrm{kg} \text {, orally }\end{array}$ & $\begin{array}{l}125.40 \pm \\
8.08\end{array}$ & $\begin{array}{l}125.56 \pm \\
8.07\end{array}$ & $\begin{array}{l}126.50 \pm \\
8.02\end{array}$ & $\begin{array}{l}127.20 \pm \\
7.08\end{array}$ & $\begin{array}{l}129.23 \pm \\
7.01\end{array}$ & $\begin{array}{l}130.40 \pm \\
8.17\end{array}$ & +4.0 \\
\hline $\mathrm{F}(\mathrm{n}=5)$ & 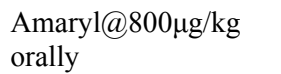 & $\begin{array}{l}125.65 \pm \\
5.13\end{array}$ & $\begin{array}{l}125.95 \pm \\
4.78\end{array}$ & $\begin{array}{l}127.45 \pm \\
4.13\end{array}$ & $\begin{array}{l}129.65 \pm \\
3.23\end{array}$ & $\begin{array}{l}131.75 \pm \\
5.13\end{array}$ & $\begin{array}{l}132.85 \pm \\
4.96\end{array}$ & +5.6 \\
\hline
\end{tabular}

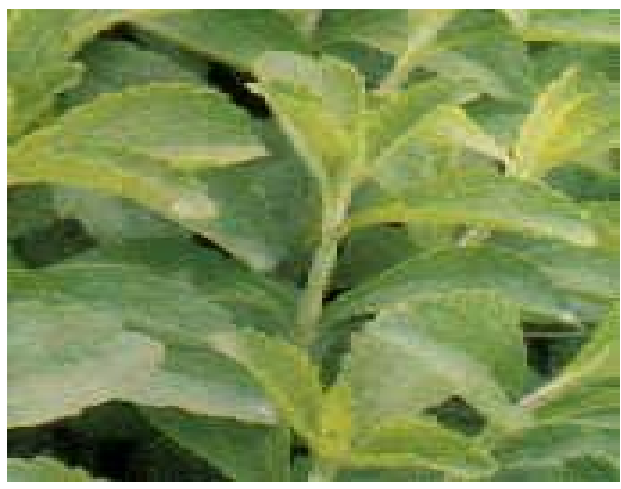

Leaves of Stevia plant

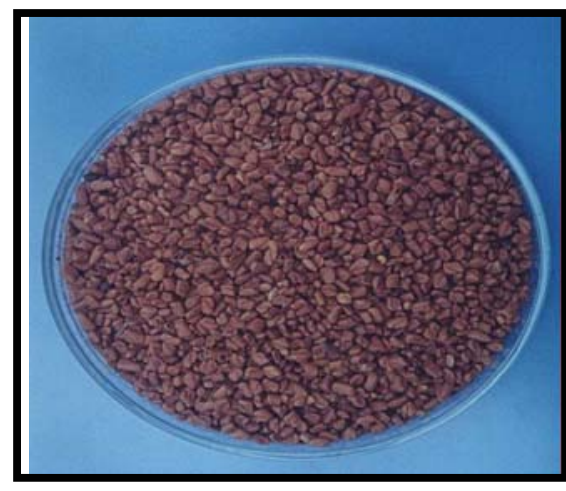

Petridish containing methi seeds

\section{REFERENCES}

1. Adams HR (1995). Veterinary Pharmacology and Therapeutics $7^{\text {th }}$ edition. Iowa State University, Press. Chapter 33. pp. 644-652.

2. Amanullah M Mustofa, Ahmed BS and Das AR (2008). Comparative efficacy of Telakucha (coccinia indica) leaves and Amaryl tablet (Glimepiride) in induced diabetes mellitus in rat J.Bangladesh Agril. Univ. 6(2):335-339.

3. Bailey CJ and Day C (1989). Traditional plant medicines as treatments for diabetes. Diabetes Care. 12:553-564

4. Cetto AA, Wiedenfeld H, Revilla MC and Segio IA (2000). Hypoglycemic effect of equisetum myriochaetum areial parts on platelet density and aggreegability in recently diagnosed type II (non-insulin- dependent) diabetic patients. Diabete-et-Metabolisme. 15(6): 420-425 


\section{Comparative efficacy of stevia lea, methi seeds and glimepiride in rats}

5. Chang JC, Wu MC, Liu IM and Cheng JT (2005). Increase of insulin sensitivity by stevioside in fructose-rich chow-fed rats. Horm Metab Res. 37:610-6.

6. Chowdhury ME (2005). Antidiabetic Effects of Azadirachta indica, Trigonella foenum-graecum, Olea europea and Glibenclamide in Experimentally Diabetic Induced Rat. M.S. Thesis, submitted to Department of Pharmacology, Bangladesh Agricultural University.

7. Cotran R, Kumar V and Robbins SL (1989). The endocrine pancreas. In: Robbins Pathologic Basis of disease, $4^{\text {th }}$.ed. W.B. Sounders Co., Philadelphia pp. 992- 1005.

8. Devi BA, Kamalakkannan N, Prince PSM (2003). Supplementation of fenugreek leaves to diabetic rats. Effect on carbohydrate metabolic enzymes in diabetic liver and kidney. Phytotherapy-Research. 2003; 17(10): 1231-1233.

9. Friedman EA (2002). Diabetic nephropathy: Improving prognosis. Saudi J Kidney Dis Trans, 2002. 13: 281-310.

10. Jeppesen PB, Gregersen S, Rolfsen SE, Jepsen M, Colombo M, Agger A, Xiao J, Kruhøffer M, Orntoft T and Hermansen K (2003). Antihyperglycemic and blood pressure-reducing effects of stevioside in the diabetic GotoKakizaki rat. Metabolism. $52: 372-8$.

11. Kamalakkannan N, Devi BA and Prince PSM. (2003). Supplementation of fenugreek leaves to diabetic rats. Effect on carbohydrate metabolic enzymes in diabetic liver and kidney. Phytotherapy-Research. 17: 1231-1233.

12. Khajuria S and Thomas J (1992). Traditional Indian beliefs about the dietary management of diabetes - An exploratory study of the implications for the management of Gujarati diabetics in Britain. J. Hum Nutr Diet.. 5: 311-321.

13. King H and Rewwers M (1991). Diabetes in adult is now a third world problem. Bulletin: World Health Organization. 69: 6430.

14. L S, Rail TW and Murad F (eds.), vol. 2, $10^{\text {th }}$ ed. The MacMillan Publishing Co., New York, Chapter 61.

15. Larner J (2001). Insulin and oral hypoglycemic drug, glucagon. In: Goodman and Gillman's the Pharmacological Basis of Therapeutics. Gilman A.G., Goodman

16. Mostofa M, Hossain MA, Sultana MR and Rima UK (2006). Anti-diabetic effects of three indigenous medicinal plants Telakucha (Coccinia indica) leaves.

17. Choudhury ME, Mostofa M and Awal MA (2006). Effects of four indigenous medicinal plants on some serum parameters in streptozotocin induced diabetic rats. J. Bangladesh Agril. Univ. 4 (2): 259 - 264.

18. Mahomed IM and Ojewole JA. 2003. Methods Find Exp. Clin. Pharmacol., 25: 617-623.

19. Marles RJ and Farnsworth NR (1995). Antidiabetic plants and their active constitutents. Phytomedicine. 2:137-189.

20. Methi (Trigonella foenum graecum) seed and Neem (Azadirachta indica) leaves and glibenclamide in streptozotocin induced diabetic rats. BAU Res. Prog. 17: 5.

21. Mostofa M., M.E, Choudhury, M.A Hossain. M.Z. Islam, M.S. Islam and M.H. Sumon (2007). Antidiabetic Effects of Catharanthus roseus, Azadirachta Indica,

22. Allium Sativum and Glimepride in experimentally Diabetic induced rat. Bangl. J. Vet. Med. 5 ( 1 \& 2 ): 99-102.

23. Oviedo CA, Franciani G and Moreno R (1979). "Action hipoglucemiante de la Stevia Rebaudiana Bertoni (Kaa-he-e)". Excerpt. Med. 209:92.

24. Raju J, Gupta J, Rao AR, Yadava PK and Baquer NZ (2001). Trigonella foenum-graecum seed powder improves glucose homeostasis in alloxan diabetic rat tissues by reversing the altered glycolytic, gluconeogenic and lipogenic enzymes. Mol. Cell. Biochem 2001 Aug;224(1-2):45-51.

25. Raskovic A, Gavrilovic M, Jakovljevic V and Sabo J (2004). Glucose concentration in the blood of intact and alloxantreated mice after pretreatment with commercial preparations of Stevia rebaudiana (Bertoni). Eur J Drug Metab Pharmacokinet. 29:87-90.

26. Sumon MH, Mostofa M, Jahan MS,.Kayesh MEH and Haque MA (2008). Comparative efficacy of Powered form of Stevia (Stevia rebaudiana bertoni )Leaves and Glime piride in Induced Diabetic Rats.. Bangl. J.Vet. Med.6(2):211-215.

27. Vats V, Grover JK, Rathi SS (2002). Evaluation of anti-hyperglycemic and hypoglycemic effect of Trigonella foenumgraecum Linn, Ocimum sanctum Linn and Pterocarpus marsupium Linn in normal and alloxanized diabetic rats. Journalof-Ethnopharmacology. 2002, 79: 1, 95-100; 22 ref. 